\title{
INVESTIGATION OF Ni-P COATINGS ON AZ91 CAST MAGNESIUM ALLOY
}

\author{
Jaromír WASSERBAUER, Martin BUCHTÍK, Roman BRESCHER \\ Materials Research Centre, Faculty of Chemistry, Brno University of Technology, Brno, Czech Republic, EU, \\ wasserbauer@fch.vut.cz
}

https://doi.org/10.37904/metal.2019.891

\begin{abstract}
In this paper, the preparation and characterization of as-deposited and heat-treated low phosphorus Ni-P coatings on AZ91 magnesium was performed. Heat-treated Ni-P coatings reached the higher microhardness of $1030 \pm 20 \mathrm{HV} 0.025$ when compared to as-deposited Ni-P coatings $(560 \pm 20 \mathrm{HV} 0.025)$. Using the scanning electron microscopy, the microstructure and surface morphology of Ni-P coatings was observed. Heat-treated coatings were formed by cracks network on their surface due to their crystallization during the heat-treatment. These cracks negatively affected the electrochemical and corrosion properties. However, asdeposited Ni-P coatings improved the electrochemical corrosion properties when compared to AZ91 alloy. The corrosion potential increased to $-0.59 \pm 0.02 \mathrm{~V}$ and the corrosion current density decreased to $1.4 \pm 0.3 \mu \mathrm{A} \cdot \mathrm{cm}^{-2}$.
\end{abstract}

Keywords: Electroless Ni-P coating, AZ91, magnesium alloy, heat treatment, potentiodynamic polarization test

\section{INTRODUCTION}

Magnesium alloys have been at the forefront of interest in many construction industries in recent years. They can replace heavier aluminum and iron alloys in a wide range of applications due to their good mechanical properties and low density. However, their widespread use is limited by their very weak corrosion resistance and high chemical reactivity [1-3].

In last years exists an effort to improve the corrosion resistance of magnesium alloys. It can be improved by various protective varnishes, metallic coatings such as galvanic, electroless or conversion coatings. The mechanical resistance of the protective layer, which is in many cases insufficient, is also one of the important aspects [2,4]. One of the possible solutions is the application of electroless Ni-P coating. Electroless Ni-P coatings on magnesium substrates exhibit very good corrosion resistance and good wearability [5]. Electroless nickel plating is a method without the need to use the electric current, while the many disadvantages associated with its galvanic counterpart are eliminated $[4,6]$.

Generally, nickel and phosphorus are deposited on the substrate surface via an autocatalytic reaction [5]. It results that the coating being deposited uniformly with minimum defects. As stated in the work of Liu [7], magnesium alloys are very active in the electroless nickel bath, so they need a special bath formulation and pre-treatments [5,8]. Many studies [9-10] are based on the fact that the substrate is homogeneous and uniform. Moreover, the plating process of some magnesium alloys becomes more complicated [7]. For example, in the case of AZ91 magnesium alloy are some problems due to the alloy microstructure heterogeneity due to the non-homogeneous distribution of $\mathrm{Al}$ in present phases - primary a-Mg solid solution, $\mathrm{Mg}_{17} \mathrm{Al}_{12}$ intermetallic phase ( $\beta$-phase), eutectic $\alpha+\beta$ phase and intermetallic AlMn phase [1]. This uneven microstructure leads to the non-uniform coating growth on the surface of magnesium alloy.

The advantage of the Ni-P coatings is their ability to control their composition by $\mathrm{pH}$ and the concentration of components in the nickel bath, or the possibility of heat treatment [8]. Riedel reports that the hardness of heattreated coatings can rises up to $1300 \mathrm{HV}$ after the treating at $400{ }^{\circ} \mathrm{C}$ for 1 hour [5]. 
The present paper reports the characterization of as-deposited and heat-treated Ni-P coatings on AZ91 magnesium alloy with an emphasis on understanding the correlation between the mechanical, microstructural and corrosion properties of AZ91 substrate and deposited coatings.

\section{EXPERIMENTAL MATERIALS AND METHODS}

AZ91 magnesium alloy with dimensions of $20 \times 20 \times 7 \mathrm{~mm}$ was used as a substrate material in the present investigation. The chemical composition of AZ91 magnesium alloy is noted in Table 1. The composition measured using the Glow-discharge optical emission spectroscopy (GDOES, Spectrumat GDS 750). This composition corresponds to the standard ASTM B90M. Before the electroless Ni-P plating process, magnesium substrates were ground using $\mathrm{SiC}$ sand paper no. 1200 to a roughness value $\mathrm{R}_{\mathrm{a}} \approx 0.1 \mu \mathrm{m}$. In the pre-treatment process, the remaining dirt and grease were removed in alkaline degreasing bath. In the last step of the pre-treatment, magnesium samples were pickled in an acid pickling bath, to increase the roughness, surface unification, and its activation. The samples were rinsed in the distilled water and isopropanol and air-dried between each step of the pre-treatment.

The deposition of Ni-P coating in the electroless nickel bath proceeded for 90 mins or 270 mins in the dependence of their next characterization. After the electroless plating, the first half of coated samples was left in the as-deposited state. Another half was heat-treated at $400{ }^{\circ} \mathrm{C}$ for 1 hour in the muffle furnace LAC LM07 (LAC, s.r.o., Czech Republic).

Table 1 Chemical composition of AZ91 magnesium alloy (wt\%)

\begin{tabular}{|c|c|c|c|c|c|c|c|c|}
\hline & Al & Zn & Cu & Mn & Si & Fe & Ni & Mg \\
\hline AZ91 & 8.80 & 0.81 & 0.00 & 0.32 & 0.01 & 0.004 & 0.00 & Bal. \\
\hline
\end{tabular}

The microstructure of plain AZ91 magnesium alloy, the surface morphology of deposited and heat-treated Ni-P coatings and their chemical composition was characterized using Zeiss Axio Observer Z1m light microscope and Zeiss EVO LS-10 (Carl Zeiss Ltd., Cambridge, UK) scanning electron microscope (SEM) with energy-dispersive spectroscopy (EDS) Oxford Instruments Xmax $80 \mathrm{~mm}^{2}$ detector (Oxford Instruments plc, Abingdon, UK) and the AZtec software (version 2.4). The microhardness of the as-deposited and heat-treated Ni-P coatings was analyzed using LECO AMH55 microhardness tester (Saint Joseph, MO, USA) from their cross-cut using the Vickers method under the applied load of $25 \mathrm{~g}$ for 10 seconds according to ASTM E384. The microhardness was calculated from ten values.

Potentiodynamic measurements were performed by the potentiostat/galvanostat Bio-Logic VSP 300 (BioLogic, Seyssinet-Pariset, France) using standard three-electrode cell. The working area was $1 \mathrm{~cm}^{2}$. The stabilization time of measured samples exposed to the $0.1 \mathrm{M} \mathrm{NaCl}$ corrosive environment was 5 minutes. The polarization range was set up from $-75 \mathrm{mV}$ to $+200 \mathrm{mV}$ vs. open circuit potential (OCP).

\section{RESULTS AND DISCUSSION}

\subsection{Microstructure of AZ91 alloy}

The microstructure of AZ91 magnesium alloy is listed in Figure 1. In the case of as-cast AZ91 alloy, the microstructure was formed by a solid solution of $\mathrm{Al}$ in $\mathrm{Mg}$ (1), intermetallic phase $\mathrm{Mg}_{17} \mathrm{Al}_{12}-\beta$ phase (2), eutectic $\alpha+\beta$ (3) and intermetallic $\mathrm{Mg}_{17} \mathrm{Al}_{12}$ in form of discontinuous precipitate (4). It was also possible to observe AIMn phase (5) (Figure 1a) [1,11]. Braszczyńska-Malik [12] states that in the case of AZ91 magnesium alloy, the aluminum-manganese phase corresponds to the composition of $\mathrm{Al}_{8} \mathrm{Mn}_{5}$ or $\mathrm{Al}_{11} \mathrm{Mn}_{4}$. After the etching of the polished substrate, the area with higher Al content (6) was observed around the discontinuous precipitate and $\mathrm{Mg}_{17} \mathrm{Al}_{12}$ phase. After the heat-treatment at $400{ }^{\circ} \mathrm{C}$ for 1 hour, the discontinuous precipitate was not observed in the 
microstructure (Figure 1b) due to the dissolution in $\alpha-M g$ solid solution. Czerwinski [11] states that during the annealing of the AZ91 alloy at $693 \mathrm{~K}$ for 24 hours, the dissolution of eutectic $\alpha+\beta$ can occur too.
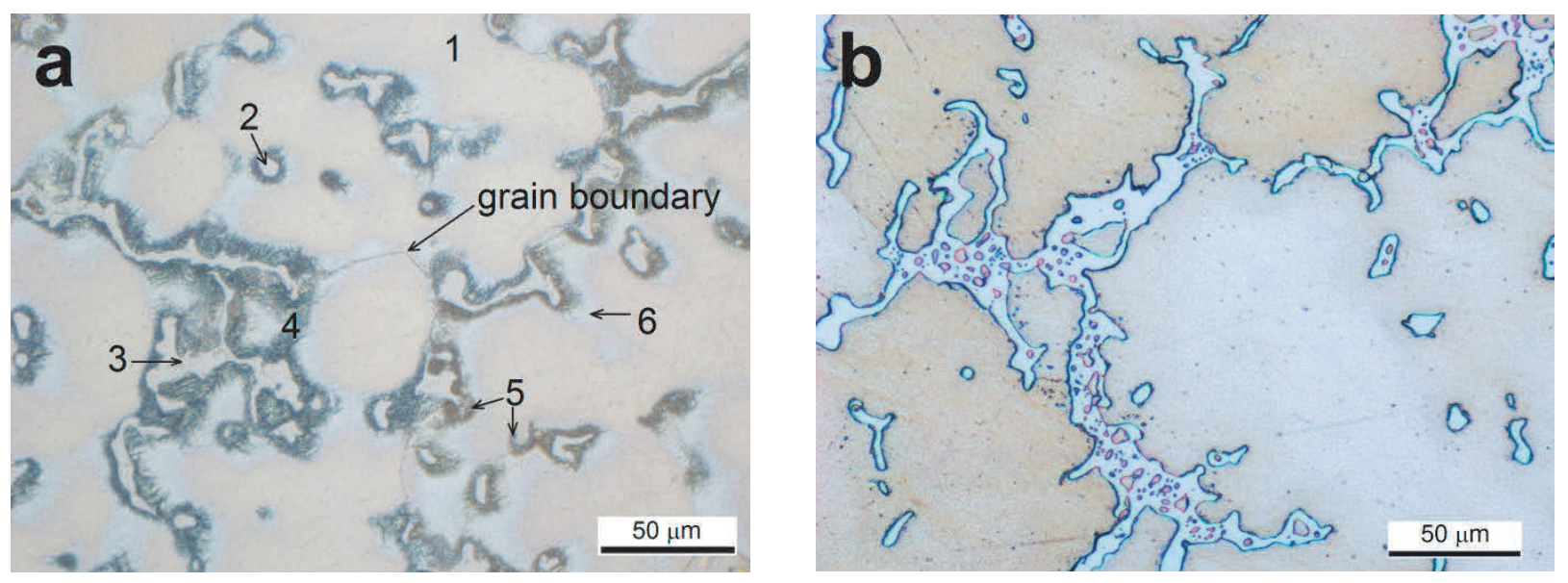

Figure 1 Microstructure of AZ91 alloy, a) cast state, b) after heat-treatment at $400{ }^{\circ} \mathrm{C}$ for 1 hour

\subsection{Characterization of Ni-P coating}

Based on the observation of the surface of Ni-P coatings (Figure 2) it was found that Ni-P coatings with 5.9 wt\% of $\mathrm{P}$ show the nodular structure. There are not visible macrodefects in the as-deposited Ni-P coating (Figure 2a) neither at the AZ91 substrate/Ni-P coating interface (Figure 2b). On the other hand, it is evident that the Ni-P coating after the heat-treatment was cracked (Figure 2c). It is because the transformation of microcrystalline as-deposited $\mathrm{Ni}-\mathrm{P}$ matrix to completely crystalline Ni-P matrix and the precipitation of $\mathrm{Ni}_{3} \mathrm{P}$ phase $[5,8]$. This process leads to the contractions resulting in cracks in the coating. From Figure $2 \mathrm{c}$ it is evident that the crack spreads across the individual nodules. Another reason for the cracking is the difference in Mg thermal expansion $\left(29 \cdot 10^{-6} \mathrm{~K}^{-1}\right)$ and the Ni-P coating thermal expansion $\left(13 \cdot 10^{-6} \mathrm{~K}^{-1}\right)[1,5]$. These cracks are extremely undesirable, especially due to the high decrease of corrosion resistance of the material. Figure $\mathbf{2} \mathbf{d}$ shows the cross-cut of heat-treated Ni-P coating with a clearly visible crack formed during the heat-treatment. This crack reaches up to the surface of magnesium alloy under the Ni-P coating. As observed from Figure 2d, the crack disrupted the part of the AZ91 substrate under the Ni-P coating. Upon the closer observation, it is apparent that the substrate was broken in the place of $\mathrm{Mg}_{17} \mathrm{Al}_{12}$ - $\beta$ phase. As literature $[1,3]$ describes, one of the disadvantages of the $\beta$ phase is its fragility. Thus, the released stress connected with the formation of the crack in the coating during the heat-treatment was sufficient to transfer the tension and the crack formation in the $\beta$ phase on the substrate surface [13].
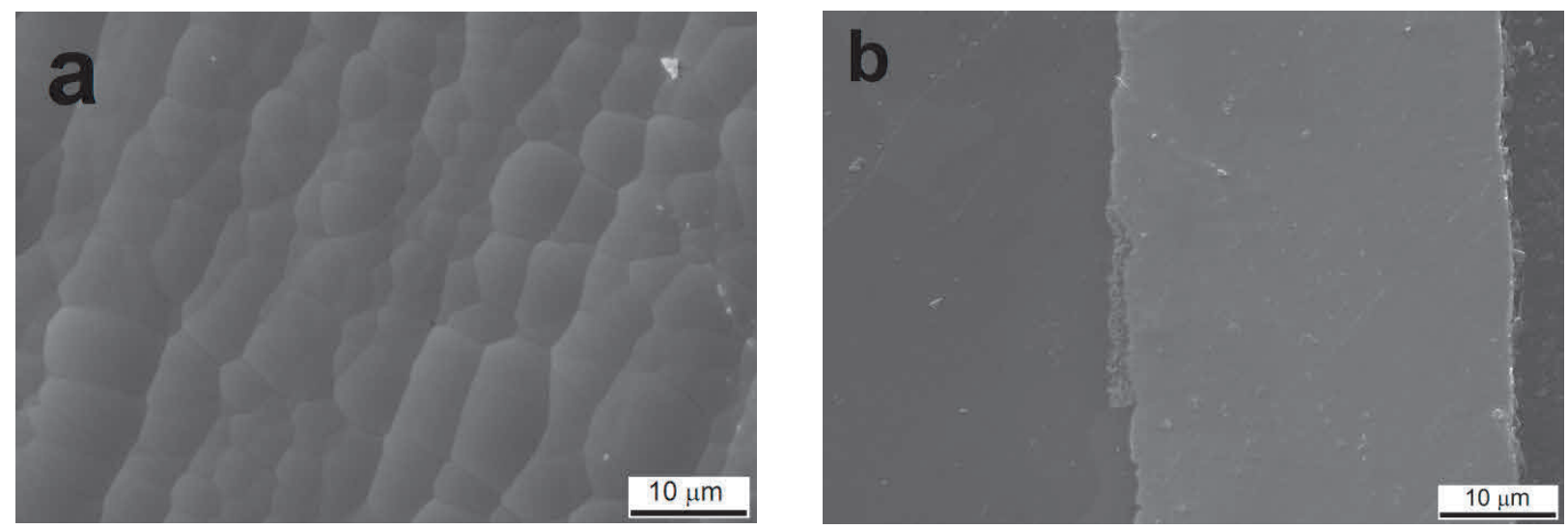

Figure 2/1 Microstructure of Ni-P coating, a) as-deposited - morphology, b) as-deposited cross-cut, c) heat-treated - morphology, d) heat-treated cross-cut 

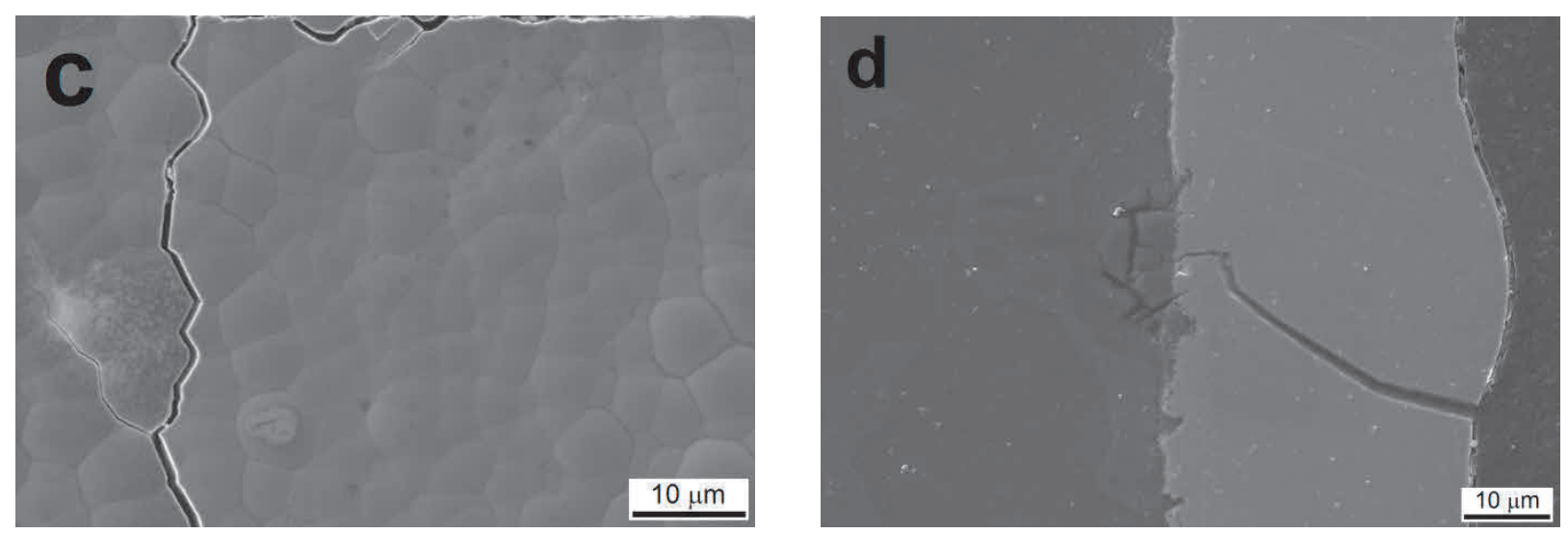

Figure 2/2 Microstructure of Ni-P coating, a) as-deposited - morphology, b) as-deposited cross-cut, c) heat-treated - morphology, d) heat-treated cross-cut

As a result of the heat-treatment at 400 ${ }^{\circ} \mathrm{C}$, the microhardness of Ni-P coating increased from $560 \pm 20 \mathrm{HV} 0.025$ to $1030 \pm 20 \mathrm{HV} 0.025$ due to the crystallization of Ni-P matrix and the precipitation of hard $\mathrm{Ni}_{3} \mathrm{P}$ intermetallic phase $[5,14,15]$. Moreover, the microhardness of AZ91 alloy (measured $\mathrm{\alpha}-\mathrm{Mg}$ solid solution) increased due to the fact that the discontinuous precipitate of $\mathrm{Mg}_{17} \mathrm{Al}_{12}$ phase (Figure 1a - 4) dissolves during the heat-treatment [11]. Due to the subsequent rapid cooling to laboratory temperature, no backward precipitation occurred. This caused the fact that the a-Mg solid solution was supersaturated

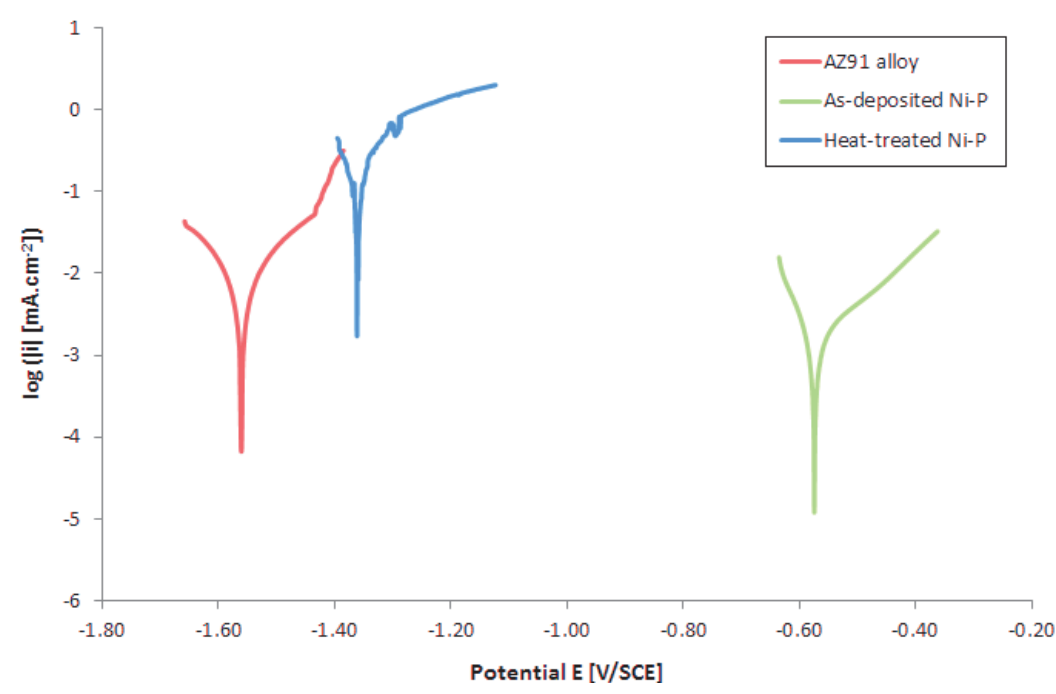

Figure 3 Potentiodynamic curves of AZ91 alloy and Ni-P coatings by aluminum after the heat-treatment [11]. This caused the increase in hardness of $\alpha-\mathrm{Mg}$ from $71 \pm 3 \mathrm{HV} 0.025$ to $78 \pm 2 \mathrm{HV} 0.025$.

Based on the potentiodynamic measurements in $0.1 \mathrm{M} \mathrm{NaCl}$ solution, it was determined that the application of asdeposited Ni-P coating has a substantial improvement in the corrosion properties of the substrate when compared to plain AZ91 alloy (Figure 3). On the other hand, the heat-treatment has an adverse effect on corrosion properties of Ni-P coating due to the presence of cracks in the coating [16]. When the corrosive solution passes to the coating/substrate interface, the corrosion rate $v_{\text {corr }}$ increased many times due to the galvanic coupling [17,18]. The individual values of corrosion potential $E_{\text {corr }}$ and corrosion current density $i_{\text {corr }}$ are noted in Table 2.

Table 2 Results of potentiodynamic measurements

\begin{tabular}{|c|c|c|c|}
\hline & $E_{\text {corr }}[\mathrm{V}]$ & $\boldsymbol{i}_{\text {corr }}\left[\mu \mathrm{A} \cdot \mathbf{c m}^{-2}\right]$ & $\boldsymbol{V}_{\text {corr }}[\mu \mathrm{mpy}]$ \\
\hline AZ91 alloy & $-1.56 \pm 0.02$ & $6.3 \pm 0.9$ & $139.67 \pm 0.54$ \\
\hline as-deposited Ni-P & $-0.59 \pm 0.02$ & $1.4 \pm 0.3$ & $31.24 \pm 1.02$ \\
\hline heat-treated Ni-P & $-1.35 \pm 0.05$ & $140.0 \pm 20.0$ & $3021 \pm 50$ \\
\hline
\end{tabular}




\section{CONCLUSION}

The work was focused on the preparation and characterization of an unconventional fluoride conversion coating created on wrought Prepared Ni-P coatings with $5.9 \mathrm{wt} \%$ of $\mathrm{P}$ was characterized by a typical nodular microstructure and the thickness uniformity.

The heat-treatment at $400{ }^{\circ} \mathrm{C}$ for 1 hour resulted in the considerable increase in the microhardness from 560 $\pm 20 \mathrm{HV} 0.025$ to $1030 \pm 20 \mathrm{HV} 0.025$. However, cracks have occurred on the surface of the heat-treated coating.

Using the potentiodynamic test it was shown that by application of as-deposited Ni-P coating, the corrosion properties improved. However, the significant decrease of corrosion properties was observed in the case of heat-treated samples due to the presence of cracks network on the surface.

\section{ACKNOWLEDGEMENTS}

This work was supported by project Nr. L01211, Materials Research Centre at FCH BUTSustainability and Development (National Programme for Sustainability I, Ministry of Education, Youth and Sports).

\section{REFERENCES}

[1] FRIEDRICH, Horst.E, MORDIKE, Barry L. Magnesium technology: metallurgy, design data, applications. 1st ed. Berlin: Springer, 2006. p. 677.

[2] BUChTíK, M., KOSÁR, P., WASSERBAUER, J., TKACZ, J. and DOLEŽAL, P. Characterization of Electroless Ni-P Coating Prepared on a Wrought ZE10 Magnesium Alloy. Coatings. 2018. vol. 3, pp. 1-14.

[3] DRÁPALA, J. et al. Hořčík, jeho slitiny a binárni systémy hořčík-príměs.1st ed. Ostrava: VŠB-TU, 2004. p. 172.

[4] KRAUS, V. Povrchy a jejich úpravy. 1st ed. Plzeň: Západočeská univerzita v Plzni, 2000. p. 218.

[5] RIEDEL, W. Electroless Nickel Plating. 1st ed. Ohio: ASM International, 1991. p. 320.

[6] FAUChAIS, P.-L., HEBERLEIN, J. V. R., BOULOS, M. I. Thermal Spray Fundamentals: From Powder to Part. 1st ed. US: Springer, 2014. p. 1587.

[7] LIU, Z., GAO, W. Electroless nickel plating on AZ91 Mg alloy substrate. Surface and Coatings Technology. 2006. vol. 200, pp. 5087-5093.

[8] MALLORY, G.O., HAJDU, J.B. Electroless Coating: Fundamentals and Applications. 2nd ed. NY: Knoyes Publishing. 2009. p. 575.

[9] SUDAGAR, J., LIAN, J., SHA, W. Electroless nickel, alloy, composite and nano coatings - A critical review. Journal of Alloys and Compounds. 2013. vol. 571, pp. 183-204.

[10] MAINIER, F.B., FONSECA, M.P.C., TAVARES, S.S.M., PARDAL, J.M. Quality of Electroless Ni-P (Nickel-Phosphorus) Coatings Applied in Oil Production Equipment with Salinity. Journal of Materials Science and Chemical Engineering. 2013. vol. 6, pp. 1-8.

[11] CZERWINSKI, F. Magnesium Alloys: Design, Processing and Properties. 1st ed. Croatia: InTech. 2011. p. 540.

[12] BRASZCZYŃSKA-MALIK, K.N., ZAWADZKI, I., WALCZAK, W., BRASZCZYŃSKI, J. Mechanical properties of highpressure. Archives of Foundry Engineering. 2008. vol. 4, pp. 15-18.

[13] HIGGS, C. E. The effect of heat treatment on the structure and hardness of an electrolessly deposited nickel-phosphorus alloy. Electrodeposition and Surface Treatment. 1974. vol. 4, pp. 315-326.

[14] AGARWALA, R. C., AGARWALA, V. Electroless alloy/composite coatings: A review. Sadhana. 2003. vol. 28, pp. 475-493.

[15] DUNCAN, R. N. The metallurgical structure of electroless nickel deposits: Effect on coating properties. Plating and Surface Finishing. 1996. vol. 11, pp. 65-69.

[16] SUN, C., GUO, X., WANG, S., GUO, J., DING, W. Homogenization pretreatment and electroless Ni-P plating on. Transactions of Nonferrous Metals Society of China. 2014. vol. 12, pp. 3825-3833.

[17] AMBAT, R., ZHOU, W. Electroless nickel-plating on AZ91D magnesium alloy: effect of substrate microstructure and plating parameters. Surface and Coatings Technology. 2004. vol. 179, pp. 124-134.

[18] SONG, G.-L. Corrosion of magnesium alloys. 1st ed. Philadelphia: Woodhead Publishing, 2011. p. 656. 